\title{
Гацаева P.C-A. \\ Проблемы и факторы формирования толерантности в современном обществе (на примере ЧР)
}

ФГБОУ ВО «Чеченский государственный университет имени А.А. Кадырова»

(Россия, Грозный)

doi: 10.18411/trnio-01-2022-131

Аннотация
В статье рассматриваются проблемы и факторы толерантности, и осмысление их.
Ключевые слова: полиэтничность, этнос, кавказоведение, толерантность,
цивилизация.

\begin{abstract}
The article examines the problems and factors of tolerance and their understanding.

Keywords: polyethnicity, ethnos, Caucasian studies, tolerance, civilization.
\end{abstract}

Исходя из актуальности проблемы толерантности для человечества, ЮНЕСКО в 1995 году принята специальная Декларация принципов толерантности. В ней толерантность понимается как «ценность и социальная норма гражданского общества», составляющими которой являются: право всех индивидов быть различными; - обеспечивая устойчивой гармонии и между различными конфессиями, политическими, этническими и другими социальными группами; уважение к разнообразию различных мировых культур, цивилизаций и народов; готовность к пониманию и сотрудничеству с людьми, различающимися по внешности, языку, убеждениям, обычаям и верованиям. Правительством РФ рекомендовано разработать соответствующие программы в республиках и регионах. Непростая задача формирования толерантности в России осложняется её многонациональностью и многоконфессиональностью, неординарным прошлым и уникальным настоящим. Его системообразующие факторы: религиозно - нравственные мировоззрение, система экзистенциальных ценностей и табуирования, природноландшафтные условия и способы хозяйствования, формы государственно - политической организации и правоотношений, которые проявляются в определенных пространственновременных рамках уникально, разновекторно, получают различную иерархию, что находит выражение в рождении и бытии самобытных региональных цивилизаций». При этом считается, что «кавказская горская цивилизация и традиционная северокавказская культура по системообразующим фактором является типологически (качественно) отличными от русской цивилизации и русской национальной культуры...». Русская цивилизация определяется православным типом духовности и эксзистенциальными ценностями, равнинными природно-ландшафтными условиями с относительно суровым климатом, община - артельными формами хозяйственной деятельности в условиях мобилизационного типа развития, государственностью как доминантной формой национальной самоорганизации, правовой культурой, не абсолютизирующей формальный закон. Кавказская горская цивилизация определяется полиэтничностью, религиозным синкретизмом, сочетанием высокогорья, предгорий и равнин, которое определяет взаимосвязь террасного земледелия, альпийского скотоводства и наездничества, закреплённых в своеобразных этических горских кодексах, психологических чертах, преобладанием форм самоорганизации. В контексте такого подхода Кавказскую войну, по мнению исследователя, «можно рассматривать как цивилизационно - культурный конфликт» [1]. Кавказская война - это длительный трагический период в истории российского северокавказских взаимоотношений, который, помимо прочего, отмечен огромными человеческими жертвами с обеих сторон. Хотя Кавказская война окончилась почти полтора века назад, её влияние на идеологическую, духовную и научную жизнь в России, прежде 
всего северокавказского региона, сохраняется до сих пор. В кавказоведении сложились два противоборствующих направления (их ещё называют двумя кавказоведениями)- «собственно русское» и «кавказское», «горское» (внутри каждого из них имеются различия и трактовке отдельных событий, фактов, личностей). Они придерживаются противоположных взглядов принципиальному вопросу Кавказской войны - вопросу о её причинах и характере. Представители первого из этих направлений выводят их из социально-экономического и политического состояния горских обществ Северного Кавказа и «набеговой системы», а представители второго-из экспансии и колониальной политики России. Такой настрой сторон объясняется тем, что их научные позиции « болезненно затрагивает национальное самосознание либо горских народов Кавказа (принижение уровня социальноэкономического развития, трактовка «хищнических» набегов как едва ли не генетической черты горцев и т. п.) либо русских (обвинение в варварском колониализме, геноциде и т. п.)»[2] Их взаимоисключающие интерпретации и оценки перекачивает школьные учебники, студенческие аудитории, средства массовой информации, сюжеты телесериалов и оказывает мощное влияние на формирование отнюдь не толерантной ориентации массового сознания. «Существенные различия в интерпретации Кавказской войны у русских и «кавказцев» (учёных и в обыденном сознании), - справедливо констатирует В.В.Черноус,- ... стали одним из факторов, придающих конфликтный характер русско - кавказскому цивилизационно культурному диалогу, распространения русофобии, кавказофобии и исламофобии». Аналогичная ситуация наблюдается также и в интерпретации таких узловых вопросов истории народов Северного Кавказа, в том числе чеченского, как происхождение (генетические корни) этих народов и территория расселения их предков. Претендуя на «коренное этнолингвистическое, генетическое родство своих предков с шумерами, египтянами, этрусками, скифо - сарматами и др... . известными этносами древних эпох...» Для адекватного научного осмысления проблематики Северного Кавказа, её народов, русско - кавказских отношений ряд учёных (А.Н.Сахаров, В.В.Чернаус, В.Ф.Петракова) считает необходимым преодолеть абсолютизацию традиционного для отечественных историков формационного, классового подхода (не отвергая всего достигнутого на этой основе) и активнее использовать новую теоретико-методологическую парадигму. В качестве таковой предполагаются геополитический и цивилизационный подходы, их сочетание, которые оцениваются как продуктивные и перспективные, так как открывают возможность для оригинального объяснения и понимания исторических процессов на Северном Кавказе. Предполагается, что движение научной мысли в этом направлении позволит сблизить нынешние полярные позиции кавказоведов. Нет сомнения, что новое поколение учёных, как и их предшественники, внесёт свой вклад в историческую науку о Северном Кавказе. Однако осуществит ли она указанный прорыв и каковы будут его результаты, покажет время. Вышеназванные и другие учёные считают также, что для преодоления в кавказоведении «конфликтной логики» исследователям необходимо: 1)беспристрастно трактовать прошлое; 2) восстановить диалог, внимательно присмотреться к позиции друг друга, прислушаться к аргументации и оппонента, принять возможность различных подходов к сложному и противоречивому историческому процессу, отказаться от приписывания друг другу злокозненных мотивов;3)перенести проблематику исключительно на поле академической науки, освободить её от политизированности, эмоциональности и взаимных подозрений и ангажированности, стремлении унизить, оскорбить национальную гордость того или иного народа;4)не забывать о чрезвычайной важности для многонационального северокавказского региона гражданской и нравственной позиции историков, ориентирующей общественность на этническую, политическую, идеологическую, конфессиональную толерантность. Представляется бесспорным, исследование кавказоведов подобным требованием действительно гармонизировало бы их взаимоотношения, а их публикации и стали бы важным фактором формирования толерантности. Разъяснительная работа в этом направлении актуальна, и послужит определённой психологической подготовке местного населения, особенно молодёжи, формированию у него установок толерантного сознания и 
поведения, что имеет принципиальное значение для профилактики возможных межэтнических коллизий. Молодёжь ЧР формировалась и формируется в практически мононациональной среде, поэтому у неё нет стабильных непосредственных контактов со своими сверстниками-представителями других этносов. Отсюда - актуальность и важность установления и всемерного расширения непосредственных контактов чеченской молодежи с учащимися и студентами других регионов России и зарубежья, активно используя для этого все доступные каналы и формы. Это позволит чеченской молодежи стать эффективным воспитывающим субъектом, играющим важную роль в преодолении ложных представлений о чеченцах, формировании толерантного отношения к ним у представителей других этносов. В свою очередь, такие контакты явятся важным фактором формирования и закрепления установок толерантного сознания и поведения у чеченской молодёжи. Рассматриваемая проблема сложна и многоаспектна, изложенным естественно, не исчерпывается и требует дальнейшего осмысления на основе глубокого и всестороннего исследования.

$$
* * *
$$

1. Черноус В.В. Культурно цивилизационное взаимодействие на Северном Кавказе :история и некоторые современные тенденции //История научные поиски и проблемы .Ростов-на-Дону: Издательство СКНЦ ВШ 2000.C.166-168

2. ПетраковаВ.Ф.,Черноус В.В. Аэрография Кавказской войны новой парадигмы// Наука о Кавказе: проблемы и перспективы. Материалы 1 съезда учёных -кавказоведов(27-28 авг.1999). Ростов-на-Дону.2000.С.110.

Гацаева P.C-A.

Современный подход к преподаванию математики в вузе

ФГБОУ ВО «Чеченский государственный университет имени А.А. Кадырова»

(Россия, Грозный)

doi: 10.18411/trnio-01-2022-132

\section{Аннотация}

Развитие высоких технологий в нашем современном мире является основой нашей жизни, что является предпосылкой и причиной потребности высококвалифицированных специалистов в области техники и компьютерной технологии.

Ключевые слова: высшая математика, прикладные задачи, математическая компетентность, инновационное обучение, инженер, методика.

\section{Abstract}

The development of high technologies in our modern world is the basis of our life, which is a prerequisite and reason for the need for highly qualified specialists in the field of engineering and computer technology.

Keywords: higher mathematics, applied problems, mathematical competence, innovative teaching, engineer, methodology.

Развитие высоких технологий требует от специалистов этого профиля проявление не только профессиональных навыков, но и знания математических методов и приемов. Стремительное развитие техники требует от специалистов принятия быстрых и оптимальных решений, но многие выпускники не готовы к решению нестандартных производственных задач. Раньше специалисту необходимо было соответствовать лишь рабочему месту и владение узкой информацией, которая необходима в определенной сфере. А обучение студентов сводилась к стандартным знаниям, умениям и навыкам, то «компетенция» предполагает овладение знаниями не только общего рода, но и в определенной широкой области, способность и готовность успешно реализовать свои умения, повышая при этом качество и эффективность своей деятельности. [2] .Разносторонняя подготовка, развития и 